Article

\title{
Firewood Collection in South Africa: Adaptive Behavior in Social-Ecological Models
}

\author{
Ulfia A. Lenfers* (1), Julius Weyl and Thomas Clemen \\ Department of Computer Science, Hamburg University of Applied Sciences, Berliner Tor 7, 20099 Hamburg, \\ Germany; Julius.weyl@haw-hamburg.de (J.W.); Thomas.clemen@haw-hamburg.de (T.C.) \\ * Correspondence: Ulfia.lenfers@haw-hamburg.de; Tel.: +49-40-42875-8411
}

Received: 8 July 2018; Accepted: 13 August 2018; Published: 15 August 2018

check for updates

\begin{abstract}
Due to the fact that the South Africa's savanna landscapes are under changing conditions, the previously sustainable firewood collection system in rural areas has become a social-ecological factor in questions about landscape management. While the resilience of savannas in national parks such as Kruger National Park (KNP) in South Africa has been widely acknowledged in ecosystem management, the resilience of woody vegetation outside protected areas has been underappreciated. Collecting wood is the dominant source of energy for rural households, and there is an urgent need for land management to find sustainable solutions for this complex social-ecological system. However, the firewood collection scenario is only one example, and stands for all "human-ecosystem service" interactions under the topic of over-utilization, e.g., fishery, grazing, harvesting. Agent-based modeling combined with goal-oriented action planning (GOAP) can provide fresh insights into the relationship between individual needs of humans and changes in land use. At the same time, this modeling approach includes adaptive behavior under changing conditions. A firewood collection scenario was selected for a proof-of-concept comprising households, collectors, ecosystem services and firewood sites. Our results have shown that, even when it is predictable what a single human agent will do, massive up-scaling is needed in order to understand the whole complexity of social-ecological systems. Under changing conditions, such as climate and an increasing population, fair distribution of natural goods become an important issue.
\end{abstract}

Keywords: firewood collection; savanna; Bushbuckridge; Kruger-to-Canyon Biosphere; goal-oriented action planning/GOAP; adaptive behavior; MARS; social-ecological systems

\section{Introduction}

Savanna landscapes, as environments with the coexistence of grass, trees, and shrubs, are natural systems with strong resilience to natural disturbances such as fire, elephants, and other herbivores [1-3]. These bi-stable systems are important in regard to socio-economic and ecological questions $[4,5]$ in a wide range of tropical and temperate regions.

South African savannas, with their unique and diverse flora, are characteristic in rural areas and millions of people benefit both directly and indirectly from these natural resources [6,7].

One of the most frequented ecosystem services is the provisioning of wood, e.g., for fuelwood, construction materials, medical issues, and livestock forage [6]. Fuelwood, such as firewood or charcoal, is the most rural energy source in sub-Sahara Africa [8]. For savanna trees and shrubs, firewood collection is sustainable when the collected material is already dead or the collection rates are below the regeneration rates [6].

To manage sustainable use, traditional authorities regulate firewood collection [7]. However, increasing settlement [9], population growth, and a decline of natural resources [10] apply pressure to the social-ecological system. Additionally, changes of land use in community areas, such as a 
mixture of various human activities [11,12] and climate change, contribute to a more unsustainable use of this energy source. Extensive clearing of trees for cooking fuel [13], agricultural expansion, and charcoal production are destroying or at least fragmenting these landscapes $[6,14]$. This increasing need and unstainable use of firewood collection requires an adaptation in the firewood collection behavior. Covering those management questions in large scale simulation studies, human behavior and decision-making is a known challenge [15].

Agent-based modeling (ABM) has a well-proven record on social-ecological systems [15-19]. Unfortunately, in most cases, these models are strictly fixed rule-based [20] and therefore, are not able to represent a realistic picture of the adaptive behavior under changing conditions.

Goal-oriented action planning (GOAP) is an artificial intelligence-based approach to overcome this obstacle [21-23]. It is widely used in game development, but we are not aware of an application to social-ecological modeling.

The authors of this study designed the firewood collection process as a goal-oriented action planning (GOAP) behavior [24] and developed a model for firewood collection in South African savanna landscape communities for this study.

\section{Materials and Methods}

\subsection{Study Side}

The Bushbuckridge district is in north-eastern South Africa next to the Kruger National Park (Figure 1).
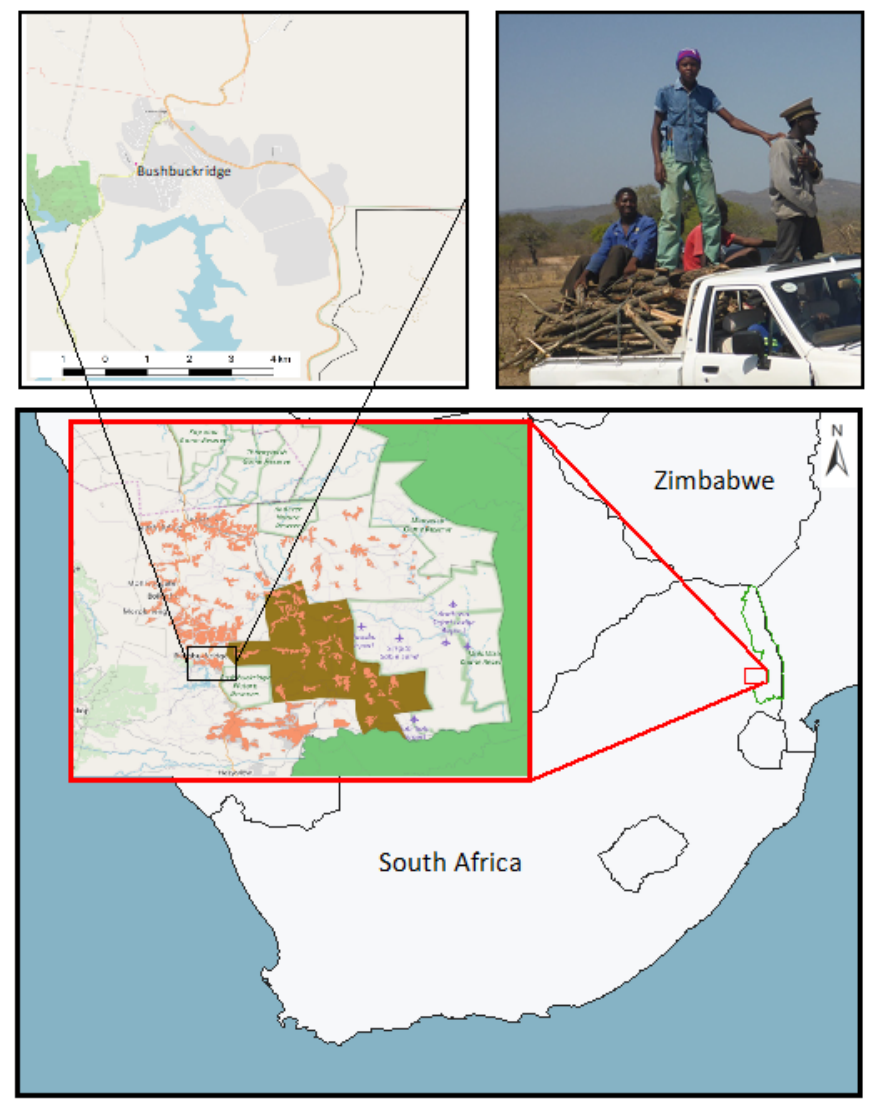

Figure 1. Location of the study site near the Kruger National Park (KNP) in the Bushbuckridge district. The picture shows transportation of firewood by car. 
Many studies about firewood collection and savanna ecosystems were conducted in the Bushbuckridge area $[8,9,25-34]$, which is also a part of the Kruger to Canyon (K2C) Biosphere Region $[9,31,32]$. The availability of excellent prior knowledge and existing long-term data make Bushbuckridge a prime geographical region for social-ecological simulation models.

In this marginalized region, the population density is around $150-350$ people per $\mathrm{km}^{2}$; unemployment is common, and the monetary income per household is low [27]. Village residents use the communal land for cultivation, grazing, and wood harvesting [35]. Using these ecosystem services is essential to rural communities [27]. The vegetation is Mixed Lowveld Bushveld with some dominant trees species like Acacia spp., Combretum apiculatum, Terminalia sericea, and Sclerocarya birrea [26,27,36,37].

\subsection{Data}

In South Africa, firewood collection is mostly carried out by females and can take up to two hours daily to collect enough wood, especially in rural areas [38]. The social regulation for firewood collection is traditionally done by local authorities [7]. Collecting wood is free of charge [39] and is used for cooking, heating water, and keeping warm [25]. Even with increasing electrification, firewood collection is done for cost saving and may increase levels of unsustainable wood harvesting $[8,33]$. Some households are able to buy firewood from local vendors [25].

Based on the information from previous studies, we summarized some key factors in Table 1. These values will later be used to parameterize our model.

Table 1. Approximate data from selected sources for the model.

\begin{tabular}{ccc}
\hline Contents & Model Input Parameter & Source \\
\hline Firewood consumption & $8 \mathrm{~kg} /$ day & {$[33]$} \\
Meals & $1-2$ cooked a day & {$[33]$} \\
Trips to collect firewood per household & 4 within a week & {$[33]$} \\
Time per trip & $2 \mathrm{~h}$ & {$[33]$} \\
Female trips on foot & $1 \mathrm{~h}-2 \mathrm{~h} 20 \mathrm{~min}$ & {$[38]$} \\
Social regulation & Authorities & {$[7]$} \\
Collecting preferences & Dead wood & {$[39]$} \\
Energy preference & Firewood (for cost saving) & {$[40]$} \\
Households with motor-car & $19.3 \%$ & {$[41]$} \\
Households with stove (electric/gas) & $78 \%$ & {$[41]$} \\
\hline
\end{tabular}

\subsection{Multi-Agent Modeling and Simulation and MARS}

Agent-based modeling incorporates artificial intelligence (AI) into modeling and simulation. Individual entities ("agents") interact with each other and their surroundings [42], e.g., an agent who is cutting down a tree interacts directly with this specific tree agent located at a geographical position. Their behavior is described on an individual level following a set of rules. It should be noted that agents can be individuals but also social groups, communities, or other entities that act and react to outer conditions [43]. These actions and reactions on an individual level may lead to a higher state of complexity, i.e., self-organization and emergence [44], which makes this approach especially suitable for research on social science [45].

The multi-agent framework MARS (Multi-Agent Research and Simulation) is under development at the University of Applied Sciences Hamburg [46] and incorporates the newest concepts of both agent-based modeling and simulation. The frameworks target both simple and complex models by using specifically designed approaches tailored to the respective disciplines such as socio-ecological systems $[47,48]$. 


\subsection{Goal-Oriented Action Planning (GOAP)}

Human behavior could be described as a sequence of decisions. Goal-oriented action planning (GOAP) derives from the field of AI and integrates adaptive decision-making into multi-agent models. Based on STRIPS (Stanford Research Institute Problem Solver), this planning algorithm aims to reach goals by executing a set of actions [49]. Each agent keeps an inner state which is represented by a set of properties (attributes). These properties are often described as Boolean predicates that evaluate to either true or false, respectively. These properties change over time and are influenced by the inner or outer sensations of the agent.

A "goal" can be described as a desired state to be reached. A hungry agent, i.e., the "IsHungry" predicate results in true ("IsHungry = true"), might follow his individual goal to change his internal state to "IsHungry = false".

Moving from one state to another is usually done by executing ("firing") a sequence of "actions". Before the "actions" are fired, a plan must be implemented to find the best sequence of actions to reach the goal [50]. Each action contains a list of preconditions that need to be fulfilled before being executed, as well as a set of postconditions that are valid after successful execution. Additionally, an action might hold a "cost" value, indicating the necessary effort for a successful execution.

The planning algorithm calculates a way of minimal costs to reach the goal. We will show that this decision-making architecture allows the agents to adapt their behavior in correspondence to a changing environment [19].

In general, GOAP would not need a software realization to work. The planning process could also be done on a sheet of paper and with a pen. If hundreds or thousands of humans are considered this task will become very time-consuming.

For this study, the MARS framework was technically extended by GOAP planning algorithms. That allows any MARS software agent to decide individually on base of an adaptive schedule.

\subsubsection{State Model}

The "state model" represents the individuality and personality of an agent. For example, an agent "Firewood Collector" may have a personal schedule, an individual set of experiences, personal traits, e.g., civil obedience, access to skills and equipment, living standards, or others.

By utilizing GOAP, each agent can plan his/her own sequence of actions as needed in order to reach a personal goal. Basically, these goals are represented by a set of values within the state model that should be achieved in the near future. The actual sequence of actions to reach that specific goal depends on the goal itself, the current state of the whole system (=world), and the individual state of the agent. Obviously, this means that even in the case of two agents sharing the same goal, their preferred sequence of actions to fulfill that goal might be without any overlap.

\subsubsection{Planning}

Planning is the process of thinking about the activities required to achieve a desired goal, often by considering constraints such as minimizing costs. If a cost value, e.g., the energy needed to execute an action, is assigned to each action, a sequence of actions will lead to total cost statement. By utilizing constraints, such as reducing total costs to a minimum value, the outcome of the planning process can be significantly changed. This can also be done on an individual level, i.e., different human agents may have individual planning constraints related to their personality or availability of resources. 
The result of the planning process is a sequence of actions that transform the current state model of an agent into the desired state formulated by the goal description. So far, GOAP planning is not too dissimilar from other planning algorithms. The major advantage might become visible when considering a change of the environment, the social network of the agent, or within the agent himself during performing this transformation. As an example, the reader might think of driving to a location, e.g., a workplace or a supermarket, when an unexpected phone call suddenly interrupts the originally planned process. A change in the form described above would lead to a re-planning process in GOAP.

\subsubsection{Actions}

An action is something that the agent is able to do, bracketed by pre- and postconditions. A precondition is a condition or predicate applied to a set of state variables that must always be true just prior to the execution of an action. Analogously, a postcondition is a condition or predicate that must be true after the execution. By that, each action changes a part of a state model, either of the world or an individual agent.

Generally, to reach a goal, a sequence of actions is necessary. Every action is encapsulated and has no immediate impact on other actions. In some cases, actions must fulfill certain criteria to determine whether they can be run. For instance, if "CuttingFirewood" has the precondition "NeedAxe", that will require a search of the immediate vicinity to see if there is an axe the agent can use. Thus, an action can trigger other actions (sub-processes) before again returning to the primary sequence.

\section{Results}

In this study, we aimed to describe the behavior of firewood collection under various changing conditions in Bushbuckridge, South Africa by using an agent-based simulation model incorporating GOAP planning. We combined existing data and knowledge of firewood collection behavior (see Table 1) and transformed this into a goal-oriented model.

The model itself is simplified in order to show that this way of modeling is suitable to express adaptive behavior under changing conditions.

\subsection{Conceptual Model}

The conceptual model is the first step in creating an agent-based model [51]. It describes, in a simple but not overly simplistic way [52], the complexity of a subset of the real world in a model. During the conceptual modeling process, modelers have to decide which subset of all concepts have to be included-and which do not. Obviously, this selection must be aligned with a specific research or management question.

In this paper, the conceptual model (see Figure 2) combines four different key elements for firewood collection. The selected components are Household, Collector, the Landscape, and Firewood site. A household aggregates one or more Family members. If the household needs firewood, one of the family members becomes a collector. The collector has to bring firewood to the household. The Landscape component provides several Ecosystem Services. One of them, firewood provisioning, is represented by a Firewood site. Collectors are able to interact with this service.

Figure 2 also shows constraints that might change over time. The steady growth of the human population certainly changes firewood collection behavior. Changes may also arise from social or political processes, land use, climate changes, or other processes.

Therefore, the interaction between the conceptual components shown in Figure 2 needs an adaptive part. This is implemented by incorporating GOAP planning. 


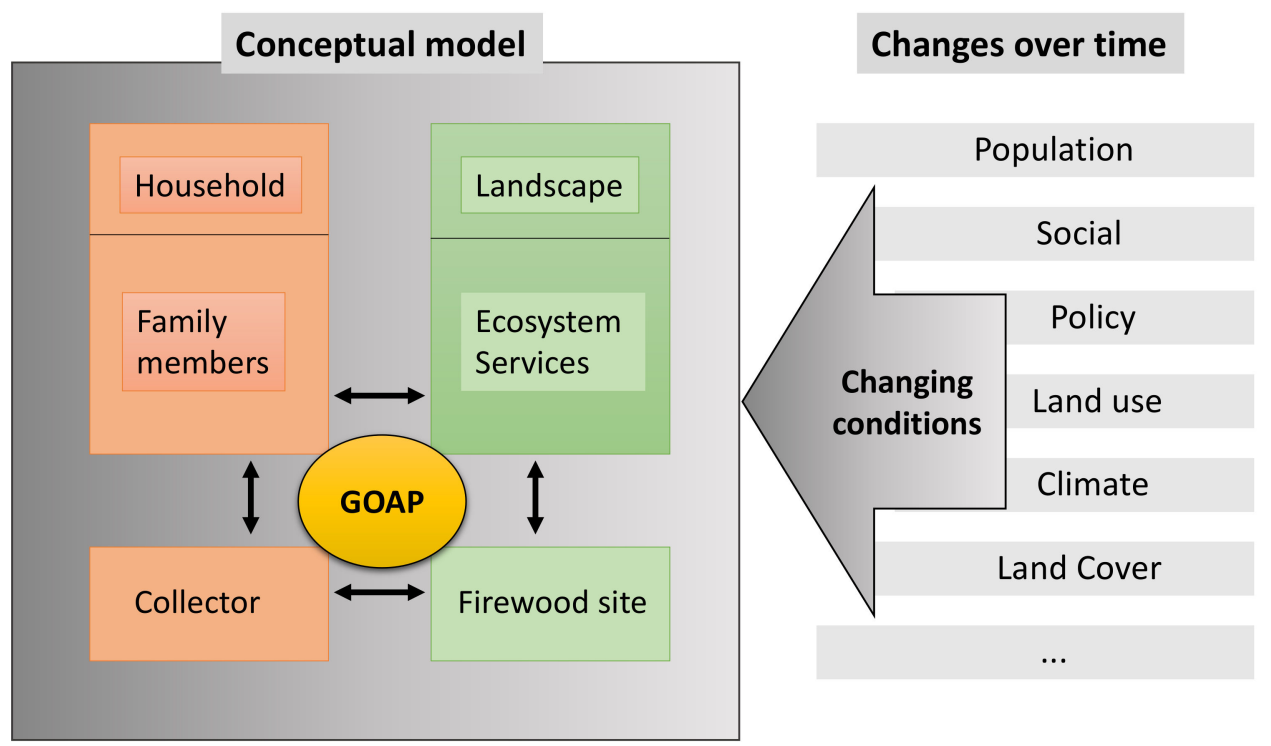

Figure 2. Conceptual model (left side) with changing conditions (right side).

\subsection{Domain Model}

Following an initial conceptual model (Figure 2), the next step is to build the domain model. For agent-based models, this means defining the agents and the environment. An agent is typically represented by attributes and methods. Here, we limit ourselves to highlighting the interaction between the firewood collector as an agent and the firewood site as part of our environment.

The agent type collector has a list of attributes such as age, gender, health condition, wood carrying capacity, and personal time schedule, among others. The combination of attributes always depends on the exact research question. As a result, for this showcase, all of our agents are without personal settings and are all able to walk, drive a car, take an axe, and collect and cut firewood. At the same time, they have the same knowledge about the firewood sites and are able to go back to their home.

For the goal-oriented action planning, in this approach, the collector agents plan their sequences of actions to bring firewood to their home. Each particular sequence of actions not only depends on the goal, but also on the different state variables of the agents and the world.

The environment here is the landscape defined by its geographical coordinates, spatial extent, and its biological diversity; it also provides several ecosystem services, e.g., firewood. In MARS scenarios, this environment is modeled by GIS files where firewood collection sites are marked points-of-interest (POI).

\subsection{Scenarios}

Simulation scenarios are a well-established approach to become aware of future challenges or changes in complex adaptive systems. For this study, the domain model described above was implemented in the MARS framework. In order to define relevant scenarios, we included possible changes over time, which actuate the system (Table 2). 
Table 2. Changing conditions with examples and the effect on firewood collection, based on literature research.

\begin{tabular}{cccc}
\hline Changing Condition & Possible Trends & Effects on Firewood Collection & Source \\
\hline Population & Increase & Higher demand for firewood & {$[8,27,40,53]$} \\
Social & Disobedience & Illegal firewood collection & {$[7]$} \\
Policy & Restriction of cutting & Fewer sites to cut firewood & {$[6]$} \\
Land use & Alternative sites & More effort to collect & {$[54]$} \\
Climate & Reduced resprouting capacity & Over-harvesting & {$[55]$} \\
Land cover & Species shift & Firewood quality & {$[54]$} \\
\hline
\end{tabular}

For firewood collection, there are several changing conditions coupled with a number of consequences of interest. Changes could be in e.g., population, the social system, policy, land use, climate, and land cover.

With regard to the system considered in this study, this list of potential changes is certainly not comprehensive. However, the broad range of aspects and their importance should be visible.

\subsection{GOAP}

As stated above, a GOAP-based planning algorithm should make firewood collectors (agents) capable of reacting to changes in their individual, social and environmental contexts. In the first step, we enhance the state model of firewood collector agents by predicates to allow the evaluation of preand postconditions.

\subsubsection{Firewood Collector}

By analyzing the firewood collection process, we identified several aspects that have a vital impact on the individual behavior of collectors. The resulting list is shown in Table 3. Obviously, the availability of time, money, and the set of tools, e.g., axes, are important factors, but respect and obedience in social hierarchical groups are also of importance.

Table 3. Table of setting for the Collector state model.

\begin{tabular}{ccc}
\hline Aspects & Predicates on States & Possible Values \\
\hline Time schedule & HasTime & True/False \\
\hline \multirow{2}{*}{ Equipment } & HasAxe & True/False \\
& HasCar & True/False \\
\hline Living standard & HasMoney & True/False \\
\hline Civil obedience & TrustChief & True/False \\
\hline \multirow{3}{*}{ Personal collecting conditions } & HasFirewood & True/False \\
& IsOnFirewoodsite & True/False \\
& BroughtFirewoodHome & True/False \\
& IsAtHome & True/False \\
\hline
\end{tabular}

"Personal collection conditions" reflect the current situation of an agent in a set of logical values.

Applying the GOAP planning algorithm to a firewood collector who has no money, no car, and no axe available achieves the action plan from Figure 3. Each action (green ellipse) is triggered by the set of preconditions and affects several state variables, as described in the "Effect" element. Figure 3 shows the "Happy Path", a basic action plan that does not consider problems or changes: simply walking to a firewood collection site, harvesting wood, and walking back home. 


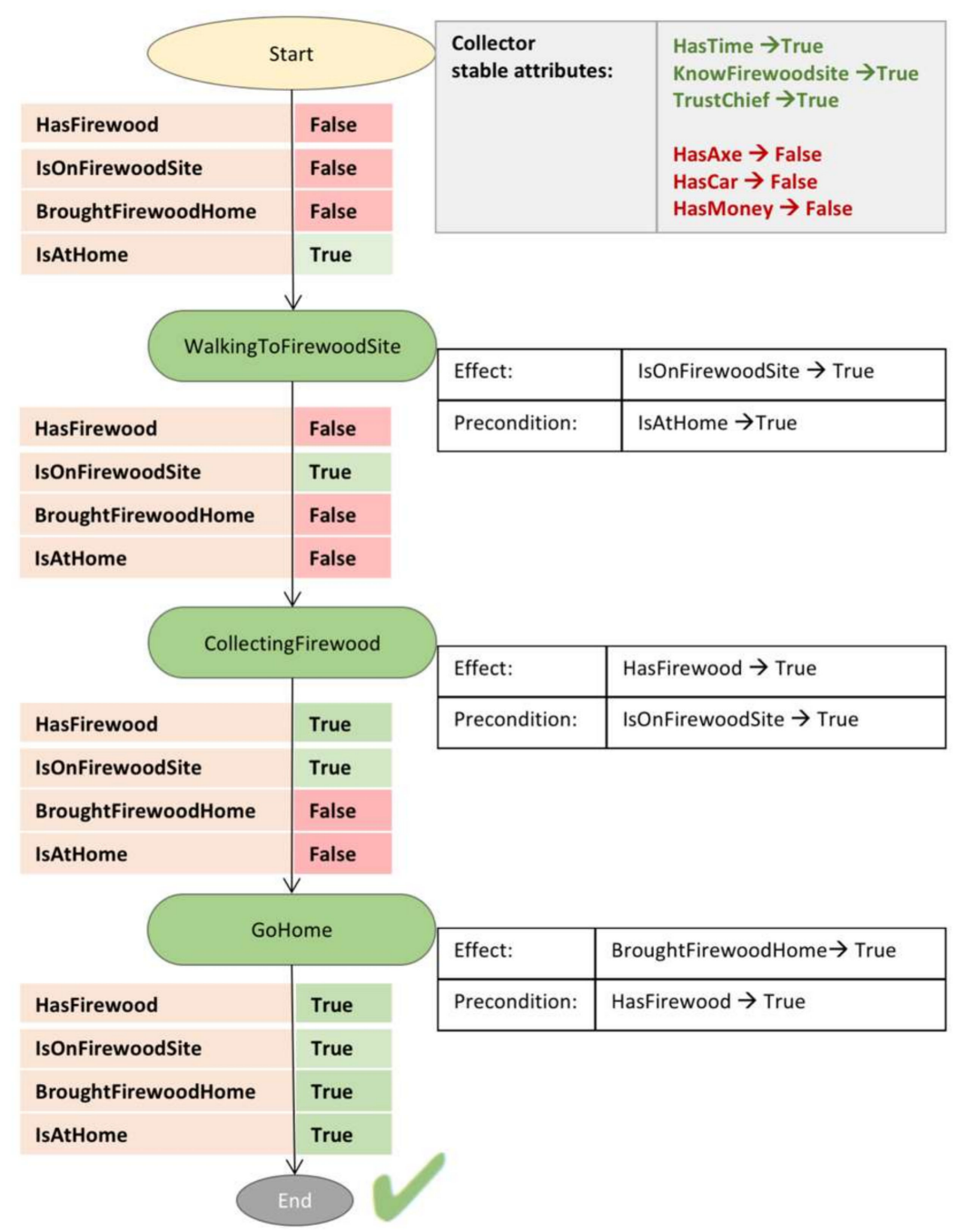

Figure 3. The "Happy Path", i.e., the most basic action plan.

However, in a non-uniform world, resources and skills are not equally distributed. That leads to different methods to acquire firewood for the household. Figure 4 shows five different action plans for firewood acquisition under variable circumstances.

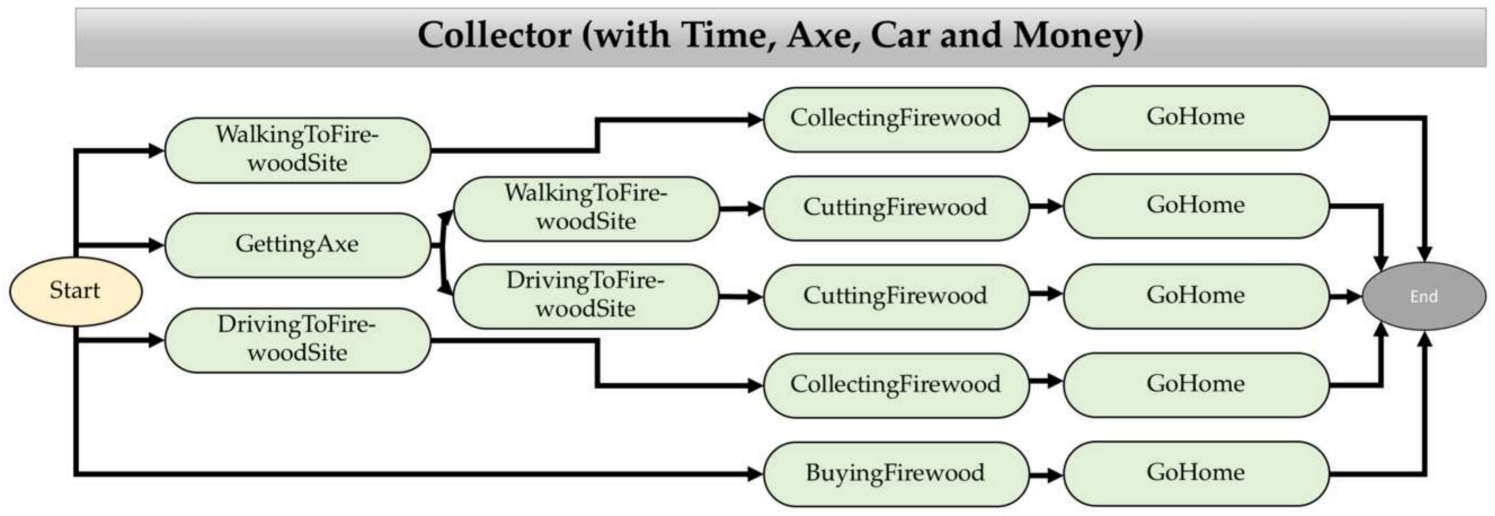

Figure 4. A composition of all possible action plans to acquire firewood for a collector with time, axe, car, and money. 
If the setting of the agent is different, e.g., the collector has no car and no money, there are fewer successful ways to fulfill the goal "HasFirewood = true" (see Figure 5).

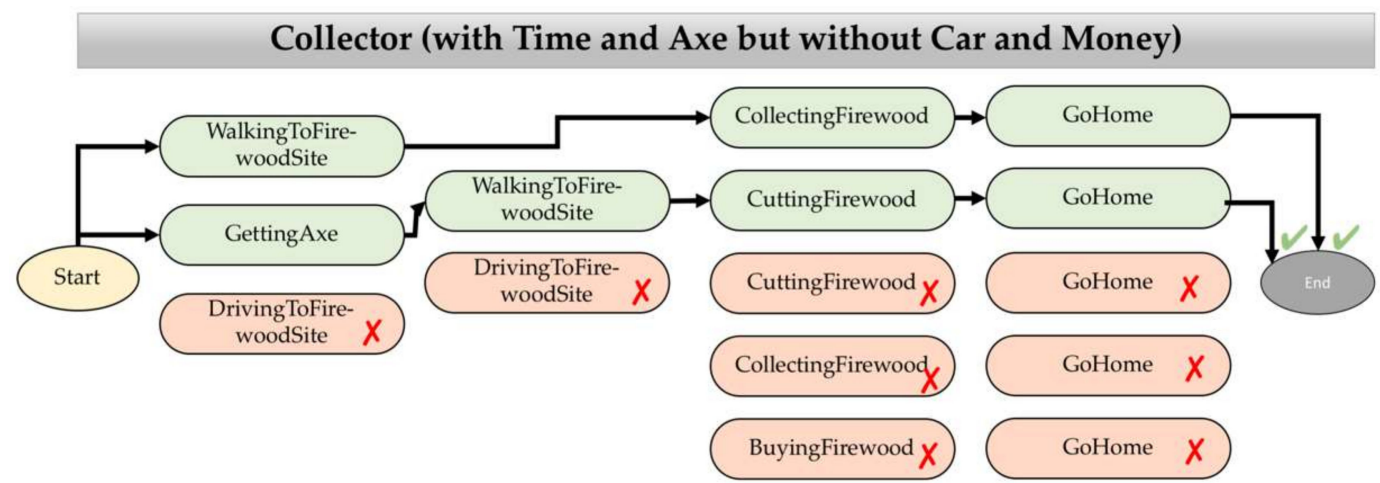

Figure 5. The composition of all actions: possible for this collector in green, impossible in red.

GOAP is a complex algorithm to calculate the various ways to fulfill a goal by taking different steps, i.e., actions. It also offers optimization criteria, for example, to find the least time consuming one. If there are more than one "optimal" action plans resulting from the GOAP planning, a random or rule-based selection can be done.

\subsubsection{Firewood Sites}

In most regions of South Africa, firewood collection takes place on official firewood sites [25]. Because the actual location of true sites is not important for this study, we placed four fictive sites $(a, b$, c, and d) with different attributes (see Table 4) into the landscape around Bushbuckridge (see Figure 6 for map).

Table 4. Characteristics of firewood collection sites.

\begin{tabular}{ccccccc}
\hline Site & $\begin{array}{c}\text { Walking } \\
\text { Distance }(\mathbf{m})\end{array}$ & $\begin{array}{c}\text { Time by } \\
\text { Walking }\end{array}$ & $\begin{array}{c}\text { Reachable } \\
\text { by Car }\end{array}$ & $\begin{array}{c}\text { Driving } \\
\text { Distance }(\mathbf{m})\end{array}$ & $\begin{array}{c}\text { Official } \\
\text { Firewood Site }\end{array}$ & Limitation \\
\hline $\mathrm{a}$ & 400 & $<3 \mathrm{~h}$ & No & - & Yes & No \\
$\mathrm{b}$ & 800 & $<3 \mathrm{~h}$ & Yes & 800 & Yes & No \\
$\mathrm{c}$ & 1500 & $<3 \mathrm{~h}$ & Yes & 1500 & Yes & No \\
$\mathrm{d}$ & 2000 & $>3 \mathrm{~h}$ & Yes & 2000 & Yes & No \\
\hline
\end{tabular}

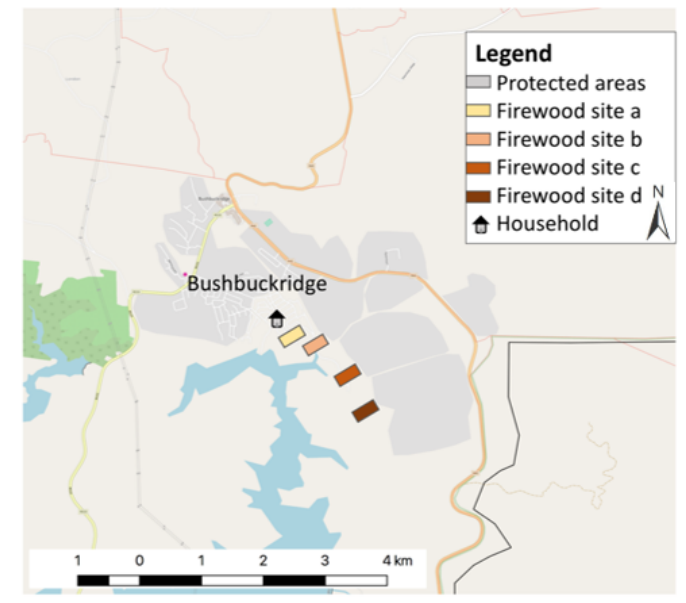

Figure 6. Map of the landscape with points-of-interest $(\mathrm{POI})=$ firewood sites. 
For the initial step of this study, we presumed that the sites are without any limitation on firewood. The three collecting sites (b), (c), and (d) are not only reachable by walking, but also by driving. Distance and time are important factors for calculating costs in this case.

\subsection{Experiments}

The preliminaries above were used to define more complex and integrated scenarios. The first experiment varied capabilities and resources of firewood collectors; the second, environmental factors; and the third, a combination of both.

\subsubsection{Agents-By Changing Attributes of Collectors}

Obviously, the most preferred site is site (a), which is both easy to reach and has plentiful collectable firewood.

We designed three different types of collector agents to represent three categories of human firewood collectors:

I Presents a collector with unlimited time but without any equipment. This type could represent a child, for example.

II Marks a stereotype for a collector which has only a maximum three-hour time limit, access to a car, and no civil obedience. Which could e.g., stand for a young man within a group who collects firewood by car.

III In this type, the collector has a higher living standard but only three hours of time.

The result of the planning process is shown in the last row of Table 5. Only type III displays deviant behavior. Which action plan is executed depends on optimization constraints, e.g., costs or time consumption.

Table 5. Attribute setting of the collector for three different scenarios and its model outcome.

\begin{tabular}{cccc}
\hline Collector Attribute & I & II & III \\
\hline HasTime $(>3 \mathrm{~h})$ & True & False & False \\
\hline HasAxe & False & True & True \\
\hline HasCar & False & True & True \\
\hline HasMoney & False & False & True \\
\hline TrustChief & True & False & True \\
\hline Outcome from GOAP & Collect on site a & Collect on site a & Collect on site $a^{*}$ \\
& & & Drive to site b and collect \\
Buy firewood
\end{tabular}

* Depends on "costs" for a car, time, and money.

By considering only this setup, a high risk of overharvesting site (a) becomes obvious.

\subsubsection{Environment-By Changing Attributes of Firewood Sites}

After creating different collector types, we designed three different settings $(A, B, C)$ for our four firewood sites $(a, b, c, d)$, each representing a different state of over-harvesting (see Table 6).

A Is a direct result after unlimited firewood collection. All dead wood on site (a) is gone, but there is living wood to cut on site (a). All other sites are still provided with dead and living firewood.

B There is no more firewood on site (a), (b), and (c), which are reachable within three hours. However, there is still both dead and living firewood on site $(\mathrm{d})$. 
C Here, we designed the opposite of unlimited firewood; there is no legal firewood on any of our four sites.

Table 6. Attribute setting of the firewood sites for three different scenarios.

\begin{tabular}{ccccl}
\hline Firewood Site & Attribute & A & B & C \\
\hline \multirow{2}{*}{ a } & HasDeadWood & False & False & False \\
& HasLivingWood & True & False & False \\
\hline \multirow{2}{*}{$\mathrm{b}$} & HasDeadWood & True & False & False \\
& HasLivingWood & True & False & False \\
\hline \multirow{2}{*}{$\mathrm{c}$} & HasDeadWood & True & False & False \\
& HasLivingWood & True & False & False \\
\hline \multirow{2}{*}{$\mathrm{d}$} & HasDeadWood & True & True & False \\
& HasLivingWood & True & True & False \\
\hline
\end{tabular}

After designing three different collector types and three different firewood site scenarios (see Tables 5 and 6), we combined them to have a total of nine different scenario outputs (see Table 7).

Table 7. Combined scenarios and model output.

\begin{tabular}{|c|c|c|c|}
\hline & $\mathbf{A}$ & B & $\mathrm{C}$ \\
\hline $\begin{array}{l}\text { Combination of } \\
\text { Changing }\end{array}$ & $\begin{array}{l}\text { (No More Dead } \\
\text { Firewood on Site a) }\end{array}$ & $\begin{array}{l}\text { (No More Dead or Living } \\
\text { Firewood on Sites } a, b, c)\end{array}$ & $\begin{array}{c}\text { (No More Legal } \\
\text { Firewood Available) }\end{array}$ \\
\hline I (time, no equipment) & $\begin{array}{l}\text { - Walk and collect at } \\
\text { site b }\end{array}$ & $\begin{array}{l}\text { - Walk and collect at } \\
\text { site d }\end{array}$ & No plan possible \\
\hline $\begin{array}{l}\text { II (poor, less time, don't } \\
\text { trust chief) }\end{array}$ & $\begin{array}{l}\text { - Walk and cut } \\
\text { firewood at site a } \\
\text { - Walk and collect at } \\
\text { site b }\end{array}$ & $\begin{array}{l}\text { Drive to site d } \\
\text { and collect }\end{array}$ & No plan possible \\
\hline $\begin{array}{l}\text { III (has everything, but } \\
\text { only less time) }\end{array}$ & $\begin{array}{l}\text { Buy firewood- } \\
\text { Drive to site b } \\
\text { and collect }\end{array}$ & Buy firewood & Buy firewood \\
\hline
\end{tabular}

Even this basic scenario setting produced a variety of different strategies:

A/I: When there is no more dead firewood on site (a), the collector without an axe (I) has to walk a longer distance to collect firewood on site (b).

A/II: If the collector has an axe but no car (II), he still can cut firewood on site a or walk to site (b) to collect there, like collector type I.

A/III: A well-situated collector (III) can buy firewood, or if he has time drive to site (b), he may collect there.

For scenario B, time is a critical attribute. The only site with firewood to collect or to cut needs more than three hours to complete the goal.

B/I: The collector I has time and is therefore able to walk the longer distance to reach site (d) and collect there.

B/II: This collector type has only three hours to bring firewood to the household, but has access to a car and can drive to site (d) to collect there. 
B/III: Because of time limitations, collector III has to buy firewood.

$\mathrm{C} / \mathrm{I}$ and C/II: If there is no more firewood available (C), there is no plan possible for collector I and II. C/III: Collector III can reach the goal by buying firewood.

By modeling with GOAP, it is plausible in this instance that there is no plan to fulfill the actual goal. However, this is not a dead end for the model; on the contrary, it serves as a way to find new solutions and to model adaptable behavior.

In this experiment, two cases did not result in a suitable sequence of actions to meet the demand. This may lead to "cascading" the problem back to the delegating entity:

$\mathrm{C} / \mathrm{I}$ For collector I, there is no chance to fulfill the goal. Therefore, after the planning, no actions are executed. The design of the model must be able to account for this. Perhaps there are alternatives in the household level.

C/II Like collector I, collector II has no chance to bring back firewood to the household. Because of his lack of civil obedience, he may be able to change his behavior, e.g., by collecting firewood outside official sites. Even if it is not currently implemented in this model, the outcome shows the modeler that something is happening, and that the model needs an improvement for this scenario.

There are also visible results at the landscape scale. The modeling is about different behaviors and adaptive decision making by people, but the results can change the landscape view; in this case, the different firewood places. Questions to be answered could be:

- Which of them are the most frequented and what will happen if these sites run out of firewood?

- What will happen if the demand for firewood increases?

For the first attempt, there is enough firewood on each collection side, so only the expenditure of reaching the area and collecting brings the decision which collecting place is best. This will be completely different when places nearby have no more firewood available. Here we are able to define a tipping point for overharvesting. If the firewood collectors need more time, money, or a vehicle, it causes changes in behavior between households with different social-economical standards.

This modeling approach also opens up options for new perspectives; for example, what happens if the collector type P gets access to electricity and an electric stove. Certainly, this will change the individual firewood collection behavior, but the question remains about how this will impact the entire system.

\section{Discussion}

Overharvesting and unstainable fuelwood extraction are contributors for land use and land cover changes (LUCC) causing a significant impact on the overall savanna ecosystem $[8,9,29,54,56]$.

The aim of this paper was to show the capabilities of modeling adaptive human behavior under changing conditions with GOAP.

Starting with a very simple initial approach and unlimited resources, we showed that the firewood collector always collects firewood in a way that requires the least effort. In our experiments, this means collecting dead wood from the nearest firewood site or, if possible, buying firewood. By increasing the options and limitations, different collector stereotypes developed varying strategies for acquiring firewood. Other modeling approaches do not support this adaptation of social-ecological behaviors [57-59].

In some cases, it became quite obvious that no suitable planning was possible. This might indicate a gap in the model description, but could also point to a possible conflict in the real world.

Moreover, our modeling approach focuses predominantly on the landscape level. Overharvesting of firewood sites, tipping points for illegal harvesting, landscape fragmentation, and the need for alternatives are important topics in modeling savanna ecology $[9,29]$. The complexity of ecosystems requires not only rule-based models $[19,58,59]$, but also adaptive agent-based models. 
We found that individual firewood collecting behavior could be modeled in an acceptable manner with GOAP. The resulting behavioral patterns fit our own observations and published results. We showed using a basic example of overharvesting, that the behavior of agents has direct consequences at the landscape level. Even the synthesized model shows this cross-scale impact well.

We observed that defining costs and thresholds using a single rating system that combines monetary values, elapsed time, and performed activities is a challenge. This subjective task should be carried out by experts, a conclusion supported by the literature $[6,33,34,39,60,61]$. In the near future, we intend enhancing and up-scaling the model by incorporating specific local conditions from Bushbuckridge, e.g., number of households and availability of firewood collection sites, together with limitations regarding more specific firewood quantities and different qualities for each firewood site $[33,62]$. Some of the extensions for achieving a more realistic model are:

- Collector: consider the effect of gender and age on different collection behaviors and distances covered; also incorporate fear of walking through potentially dangerous areas;

- Household: differentiate households based on different amounts of firewood needed, availability of electricity, income levels, and the number of household members;

- Landscape: include illegal firewood sites and locations of alternative energy sources, like dung;

- Firewood site: distinguish between different qualities of firewood.

However, it is expected that the greatest increase in knowledge will result from the massive up-scaling, i.e., by increasing the number of households and collectors competing for firewood in a region. What will happen if all accessible collection sites are overharvested or if, due to climate change, there is a shift in tree and bush species? Exploring these scenarios will include thousands, perhaps millions, of individuals with high variability in intentions, goals and capabilities.

Dealing with the increasing complexity requires sophisticated and cross-scale simulation models. Only then can decision-makers and on-the-ground managers be better supported by scientists. The adaptive manner of this modeling approach also allows system experts to gain a better mechanistic understanding of the specific social-ecological system. Emerging behavior, and patterns of self-organization are worthwhile properties to look for as well as tipping-points in the system.

\section{Conclusions}

The understanding of human-nature interaction is an important step for achieving sustainable management solutions in the context of social-ecological systems.

Management decisions are often achieved by personal experiences, abilities, and within hierarchical structures. Under changing conditions, such as climate and an increasing population, the decision-making process becomes more complex. These experiences bring a high risk of ecological and social degradations.

For decision makers it is predictable that, each single household will exploit the closest firewood site and travel further when the closest sites are exhausted. Consequently, the knowledge growth will come when the upscaling for hundreds, thousands, or millions of households is observed.

The MARS framework is exactly developed for these massive number of individual agents in highly complex social-ecological systems. To understand the processes that lead to emerging phenomena, tipping points, or self-organization decision makers need such powerful frameworks.

Because of the higher demand and the potential loss of all ecosystem services, there is a high demand for suitable modeling approaches that carter for solutions for the worldwide problems.

The presented approach for adaptive planning of human behavior in agent-based modeling and simulation scenarios based on artificial intelligence are practical for all kinds of social-ecological modeling-especially, for limited natural resources like water, food, and fuel wood.

These promising results will lead to an expansion of the model in the near future. 
Author Contributions: This work originated from the Department of Computer Science at Hamburg University of Applied Sciences. U.A.L. conceptualized the model and designed the study; T.C. and J.W. did the software design and implementation in MARS. U.A.L. conducted the experiments and did all analysis and visualization. T.C. and J.W. critically reviewed the paper and provided comments on its content and structure.

Funding: This study was partly funded by the German Federal Ministry of Research for the project ARS AfricaE (FKZ 01LL1303A).

Acknowledgments: We acknowledge the financial support by the Hamburg University of Applied Sciences for funding the open access publication.

Conflicts of Interest: The authors declare no conflict of interest.

\section{References}

1. Staver, A.C.; Archibald, S.; Levin, S. Tree cover in sub-Saharan Africa: Rainfall and fire constrain forest and savanna as alternative stable states. Ecology 2011, 92. [CrossRef]

2. Kruger, L.M.; Bond, W.J.; Midgley, J.J.; Balfour, D.A. Disturbance Gradients and Biome Boundaries in the Hluhluwe-iMfolozi Park. In Conserving Africa's Mega-Diversity in the Anthropocene; Cromsigt, J.P.G.M., Archibald, S., Owen-Smith, N., Eds.; Cambridge University Press: Cambridge, UK, 2017; pp. 189-209, ISBN 9781139382793.

3. Beale, C.M.; Van Rensberg, S.; Bond, W.J.; Coughenour, M.; Fynn, R.; Gaylard, A.; Grant, R.; Harris, B.; Jones, T.; Mduma, S.; et al. Ten lessons for the conservation of African savannah ecosystems. Biol. Conserv. 2013, 167, 224-232. [CrossRef]

4. Scholes, R.J.; Walker, B.H. An African Savanna-Synthesis of the Nylsvley Study; Cambridge University Press: Cambridge, UK, 1993.

5. Scholes, R.J.; Archer, S.R. Tree Grass Interactions in Savannas. Annu. Rev. Ecol. Syst. 1997, 28, 517-544. [CrossRef]

6. Woollen, E.; Ryan, C.M.; Baumert, S.; Vollmer, F.; Grundy, I.; Fisher, J.; Fernando, J.; Luz, A.; Ribeiro, N.; Lisboa, S.N. Charcoal production in the Mopane woodlands of Mozambique: What are the trade-offs with other ecosystem services? Philos. Trans. R. Soc. B Biol. Sci. 2016, 371. [CrossRef] [PubMed]

7. Findlay, S.; Twine, W. Chiefs in a Democracy: A Case Study of the 'New' Systems of Regulating Firewood Harvesting in Post-Apartheid South Africa. Land 2018, 7, 35. [CrossRef]

8. Wessels, K.J.; Colgan, M.S.; Erasmus, B.F.N.; Asner, G.P.; Twine, W.C.; Mathieu, R.; Van Aardt, J.A.N.; Fisher, J.T.; Smit, I.P.J. Unsustainable fuelwood extraction from South African savannas. Environ. Res. Lett. 2013, 8. [CrossRef]

9. Coetzer, K.L.; Erasmus, B.F.N.; Witkowski, E.T.F.; Bachoo, A.K. Land-cover change in the Kruger to Canyons Biosphere Reserve 1993-2006: A first step towards creating a conservation plan for the subregion. S. Afr. J. Sci. 2010, 106, 1-10. [CrossRef]

10. Ofoegbu, C.; Chirwa, P.W.; Francis, J.; Babalola, F.D. Assessing local-level forest use and management capacity as a climate-change adaptation strategy in Vhembe district of South Africa. Clim. Dev. 2018. [CrossRef]

11. Aspinall, R.; Staiano, M. A Conceptual Model for Land System Dynamics as a Coupled Human-Environment System. Land 2017, 6, 81. [CrossRef]

12. Giannecchini, M.; Twine, W.; Vogel, C. Land-cover change and human-environment interactions in a rural cultural landscape in South Africa. Geogr. J. 2007, 173, 26-42. [CrossRef]

13. Kirkland, T.; Hunter, L.M.; Twine, W. “The Bush is No More": Insights on Institutional Change and Natural Resource Availability in Rural South Africa. Soc. Nat. Resour. 2007, 20, 337-350. [CrossRef] [PubMed]

14. Fisher, J.T.; Witkowski, E.T.F.; Erasmus, B.F.N.; Van Aardt, J.; Asner, G.P.; Wessels, K.J.; Mathieu, R. Human-modified landscapes: Patterns of fine-scale woody vegetation structure in communal savannah rangelands. Environ. Conserv. 2012, 39, 72-82. [CrossRef]

15. Badmos, B.; Agodzo, S.; Villamor, G.; Odai, S. An Approach for Simulating Soil Loss from an Agro-Ecosystem Using Multi-Agent Simulation: A Case Study for Semi-Arid Ghana. Land 2015, 4, 607-626. [CrossRef]

16. Bakker, M.M.; Alam, S.J.; van Dijk, J.; Rounsevell, M.D.A. Land-use change arising from rural land exchange: An agent-based simulation model. Landsc. Ecol. 2014, 30, 273-286. [CrossRef] 
17. Cioffi-Revilla, C.; Rogers, J.D.; Hailegiorgis, A. Geographic Information Systems and Spatial Agent-Based Model Simulations for Sustainable Development. Tist 2011, 3, 1-11. [CrossRef]

18. Machado, R.B.; Macchiavello, B.; Zaghetto, A.; Coelho, C.G.C.; Abreu, C.G.; Ralha, C.G. A multi-agent model system for land-use change simulation. Environ. Model. Softw. 2013, 42, 30-46. [CrossRef]

19. Le, Q.B.; Park, S.J.; Vlek, P.L.G.; Cremers, A.B. Land-Use Dynamic Simulator (LUDAS): A multi-agent system model for simulating spatio-temporal dynamics of coupled human-landscape system. I. Structure and theoretical specification. Ecol. Inform. 2008, 3, 135-153. [CrossRef]

20. Grimm, V.; Berger, U.; DeAngelis, D.L.; Polhill, J.G.; Giske, J.; Railsback, S.F. The ODD protocol: A review and first update. Ecol. Model. 2010, 221, 2760-2768. [CrossRef]

21. Orkin, J. Applying Goal-Oriented Action Planning to Games. In AI Game Program. Wisdom 2; Charles River Media: Boston, MA, USA, 2003; pp. 217-227.

22. Bjarnolf, P.; Gustavsson, P.M.; Brax, C. Threat Analysis Using Goal-Oriented Action Planning. Available online: https:/ / www.researchgate.net/profile/Per_Gustavsson/publication/259476495_Threat_Analysis_ Using_Goal-Oriented_Action_Planning/links/0c96052c05e726386f000000.pdf (accessed on 14 August 2018).

23. Thiel-Clemen, T.; Klingenberg, A. Kombination von zielorientiertem Verhalten und Emotionen in Individuen-orientierten Simulationen. In Simulation in den Umwelt- und Geowissenschaften, Workshop Osnabrïck; Shaker Verlag: Herzogenrath, Germany, 2010; pp. 71-80.

24. Deadman, P.; Gimblett, R.H. A Role for Goal-Oriented Autonomous Agents in Modeling People-Environment Interactions in Forest Recreation. Comput. Model. 1994, 20, 121-133. [CrossRef]

25. Madubansi, M.; Shackleton, C.M. Changes in fuelwood use and selection following electrification in the Bushbuckridge lowveld, South Africa. J. Environ. Manag. 2007, 83, 416-426. [CrossRef] [PubMed]

26. Emanuel, P.L.; Shackleton, C.M.; Baxter, J.S. Modelling the sustainable harvest of Sclerocarya birrea subsp. caffra fruits in the South African lowveld. For. Ecol. Manag. 2005, 214, 91-103. [CrossRef]

27. Rutherford, M.C.; Mucina, L.; Lötter, C.; Bredenkamp, G.J.; Jacobus, H.L.; Scott-shaw, C.R.; Hoare, D.B.; Goodman, S.; Bezuidenhout, H.; Scott, L.; et al. Savanna Biome. In The Vegetation of South Africa, Lesotho and Swaziland; SANBI: Pretoria, South Africa, 2006; pp. 439-539.

28. Leakey, R.; Pate, K.; Lombard, C. Domestication potential of Marula (Sclerocarya birrea subsp caffra) in South Africa and Namibia: 2. Phenotypic variation in nut and kernel traits. Agrofor. Syst. 2005, 64, 37-49. [CrossRef]

29. Mograbi, P.; Asner, G.; Witkowski, E.; Erasmus, B.; Wessels, K.; Mathieu, R.; Vaughn, N. Humans and elephants as treefall drivers in African savannas. Ecography 2016. [CrossRef]

30. Coetzer, K.L.; Erasmus, B.F.N.; Witkowski, E.T.F.; Reyers, B. The race for space: Tracking land-cover transformation in a socio-ecological landscape, South Africa. Environ. Manag. 2013, 52, 595-611. [CrossRef] [PubMed]

31. Coetzer-Hanack, K.L.; Witkowski, E.T.F.; Erasmus, B.F.N. Thresholds of change in a multi-use conservation landscape of South Africa: Historical land-cover, future transformation and consequences for environmental decision-making. Environ. Conserv. 2016, 43, 253-262. [CrossRef]

32. Williams, A.; Shackleton, C.M. Fuelwood use in South Africa: Where to in the 21st century? S. Afr. For. J. 2002, 196, 1-7.

33. Matsika, R.; Erasmus, B.F.N.; Twine, W.C. Double jeopardy: The dichotomy of fuelwood use in rural South Africa. Energy Policy 2013, 52, 716-725. [CrossRef]

34. Matsika, R.; Erasmus, B.F.N.; Twine, W.C. A tale of two villages: Assessing the dynamics of fuelwood supply in communal landscapes in South Africa. Environ. Conserv. 2013, 40, 71-83. [CrossRef]

35. Shackleton, C.M.; Griffin, N.J.; Banks, D.I.; Mavrandonis, J.M.; Shackleton, S.E. Community Structure and Species Composition along a Disturbance Gradient in a Communally Managed South-African Savanna. In Vegetatio; Springer: New York, NY, USA, 1994; Volume 115, pp. 157-167, ISBN 0042-3106.

36. Powrie, L.; Rutherford, M.C.; Mucina, L.; Mangwale, K. National Vegetation Database of South Africa. Biodivers. Ecol. 2012, 4. [CrossRef]

37. Helm, C.V.; Witkowski, E.T.F.; Kruger, L.; Hofmeyr, M.; Owen-Smith, N. Mortality and utilisation of Sclerocarya birrea subsp. Caffra between 2001 and 2008 in the Kruger National Park, South Africa. S. Afr. J. Bot. 2009, 75, 475-484. [CrossRef] 
38. Charmes, J. A Review of Empirical Evidence on Time Use in Africa from UN-Sponsored Surveys; The World Bank: Washington, DC, USA, 2006, ISBN 0-8213-6561-4.

39. May-Tobin, C. Wood for Fuel. In The Root of the Problem: What's Driving Tropical Deforestation Today? Union of Concerned Scientists: Cambridge, MA, USA, 2011; pp. 79-87.

40. Mosa, A.; Siddig, K.; Grethe, H. Time use for Home Activities, Market Activities and Leisure in Ethiopia: Economy-wide effects of improved efficiency. In Proceedings of the 19th Annual Conference on Global Economic Analysis, Washington DC, USA, 15-17 June 2016; pp. 1-16.

41. Community Survey 2016: Statistics South Africa (2016) South African Community Survey 2016. Indicators Derived from the Full Population Community Survey. Available online: https:/ / wazimap.co.za/profiles / municipality-MP325-bushbuckridge/\#citations (accessed on 24 July 2018).

42. Gilbert, N.; Troitzsch, K. Simulation for the Social Scientist; Open University Press: Berkshire, UK, 2005, ISBN 0335216005.

43. Helbing, D.; Balietti, S. Social Self-Organization. Time 2012, 1-55. [CrossRef]

44. An, L. Modeling human decisions in coupled human and natural systems: Review of agent-based models. Ecol. Model. 2012, 229, 25-36. [CrossRef]

45. Axelrod, R. Advancing the art of simulation in the social sciences. Complexity 1997, 3, 16-22. [CrossRef]

46. Hüning, C.; Dalski, J.; Adebahr, M.; Lenfers, U.; Thiel-Clemen, T.; Grundmann, L. Modeling \& simulation as a service with the massive multi-agent system MARS. In Simulation Series; Society for Computer Simulation International: San Diego, CA, USA, 2016; Volume 48, pp. 1-8.

47. Glake, D.; Weyl, J.; Hüning, C.; Dohmen, C.; Clemen, T. Modeling through Model Transformation with MARS 2.0. In Proceedings of the 2017 Spring Simulation Multiconference, Virginia Beach, VA, USA, $23-26$ April 2017; p. 12.

48. Weyl, J.; Glake, D.; Clemen, T. Agent-based Traffic Simulation at City Scale with MARS. In Proceedings of the 2018 Spring Simulation Multiconference, Baltimore, MD, USA, 15-18 April 2018.

49. Fikes, R.E.; Nilsson, N.J. Strips: A new approach to the application of theorem proving to problem solving. Artif. Intell. 1971, 2, 189-208. [CrossRef]

50. Pittman, D. Practical Development of Goal-Oriented Action Planning AI. Master's Thesis, Southern Methodist University, Dallas, TX, USA, 2007.

51. Thiel-Clemen, T. Designing Good Individual-based Models in Ecology. In Simulation in den Umwelt- und Geowissenschaften, Workshop Leipzig; Wittmann, J., Müller, M., Eds.; Shaker Verlag: Herzogenrath, Germany, 2013; pp. 97-106.

52. Lenfers, U.A.; Brüggemann, R.; Thiel-Clemen, T. Von der Komplexität der Wirklichkeit hin zum Modell: Einsatz partieller Ordnungen bei der Modellentwicklung. In Simulation in Umwelt- und Geowissenschaften, Workshop Hamburg; Berichte aus der Umweltinformatik, ASIM Mitteilung AM 161; Shaker: Aachen, Germany, 2016; pp. 7-17. ISBN 978-3-8440-4770-7.

53. Mohammed, Y.S.; Bashir, N.; Mustafa, M.W. Overuse of wood-based bioenergy in selected sub-Saharan Africa countries: Review of unconstructive challenges and suggestions. J. Clean. Prod. 2015, 96, 501-519. [CrossRef]

54. Crews, K.; Young, K. Forefronting the Socio-Ecological in Savanna Landscapes through Their Spatial and Temporal Contingencies. Land 2013, 2, 452-471. [CrossRef]

55. Barbosa, E.R.M.; van Langevelde, F.; Tomlinson, K.W.; Carvalheiro, L.G.; Kirkman, K.; de Bie, S.; Prins, H.H.T. Tree species from different functional groups respond differently to environmental changes during establishment. Oecologia 2014, 174, 1345-1357. [CrossRef] [PubMed]

56. Higgins, S.I.; Scheiter, S. The stability of African savannas: Insights from the indirect estimation of the parameters of a dynamic model. Ecology 2010. [CrossRef]

57. Schlüter, M.; Baeza, A.; Dressler, G.; Frank, K.; Groeneveld, J.; Jager, W.; Janssen, M.A.; McAllister, R.R.J.; Müller, B.; Orach, K.; et al. A framework for mapping and comparing behavioural theories in models of social-ecological systems. Ecol. Econ. 2017, 131, 21-35. [CrossRef]

58. Polhill, J.G.; Filatova, T.; Schlüter, M.; Voinov, A. Modelling systemic change in coupled socio-environmental systems. Environ. Model. Softw. 2016, 75, 318-332. [CrossRef] 
59. Moncrieff, G.R.; Scheiter, S.; Slingsby, J.A.; Higgins, S.I. Understanding global change impacts on South African biomes using Dynamic Vegetation Models. S. Afr. J. Bot. 2015, 101, 16-23. [CrossRef]

60. Démurger, S.; Fournier, M. Poverty and firewood consumption: A case study of rural households in northern China. China Econ. Rev. 2011, 22, 512-523. [CrossRef]

61. Joshi, J.; Bohara, A.K. Household preferences for cooking fuels and inter-fuel substitutions: Unlocking the modern fuels in the Nepalese household. Energy Policy 2017, 107, 507-523. [CrossRef]

62. Lenfers, U.A.; Bruggemann, R.; Clemen, T. Exploring survival strategies of African Savanna trees by partial ordering techniques. Ecol. Inform. 2017, 42, 14-23. [CrossRef]

(C) 2018 by the authors. Licensee MDPI, Basel, Switzerland. This article is an open access article distributed under the terms and conditions of the Creative Commons Attribution (CC BY) license (http:/ / creativecommons.org/licenses/by/4.0/). 